2013-02

Exogenous application of molybdenum affects the expression of CBF14 and the development of frost tolerance in wheat

\author{
Al-Issawi, M \\ http://hdl.handle.net/10026.1/1260
}

10.1016/j.plaphy.2012.11.010

Plant Physiology and Biochemistry

Elsevier BV

All content in PEARL is protected by copyright law. Author manuscripts are made available in accordance with publisher policies. Please cite only the published version using the details provided on the item record or document. In the absence of an open licence (e.g. Creative Commons), permissions for further reuse of content should be sought from the publisher or author. 
Provided for non-commercial research and education use. Not for reproduction, distribution or commercial use.

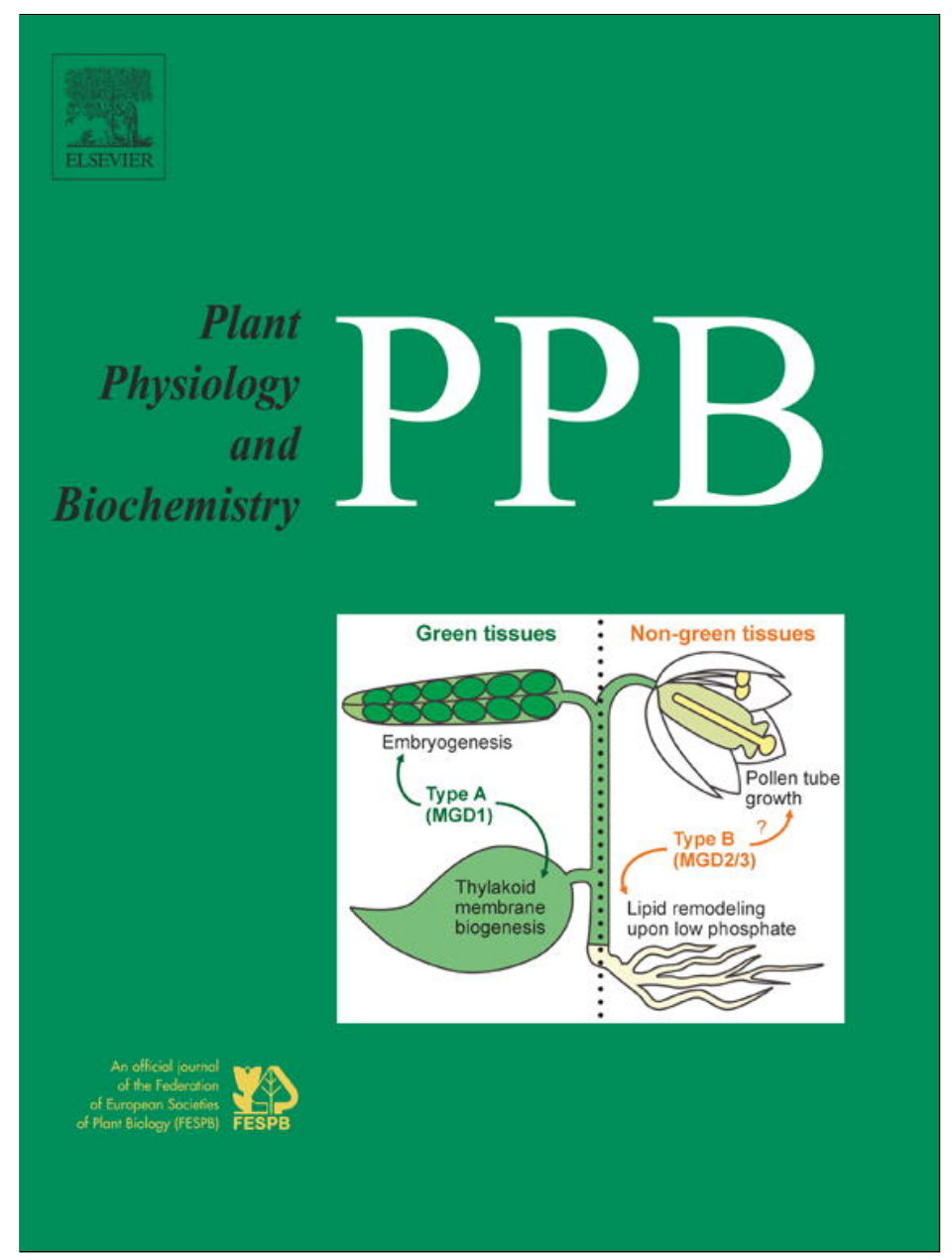

(This is a sample cover image for this issue. The actual cover is not yet available at this time.)

This article appeared in a journal published by Elsevier. The attached copy is furnished to the author for internal non-commercial research and education use, including for instruction at the authors institution and sharing with colleagues.

Other uses, including reproduction and distribution, or selling or licensing copies, or posting to personal, institutional or third party websites are prohibited.

In most cases authors are permitted to post their version of the article (e.g. in Word or Tex form) to their personal website or institutional repository. Authors requiring further information regarding Elsevier's archiving and manuscript policies are encouraged to visit:

http://www.elsevier.com/copyright 
Research article

\title{
Exogenous application of molybdenum affects the expression of CBF14 and the development of frost tolerance in wheat
}

\author{
Mohammed Al-Issawi ${ }^{\mathrm{a}, \mathrm{b}}$, Hail Z. Rihan ${ }^{\mathrm{a}}$, Wondwossen Abate Woldie ${ }^{\mathrm{a}}$, Stephen Burchett ${ }^{\mathrm{a}}$, \\ Michael P. Fuller ${ }^{\mathrm{a}, *}$ \\ ${ }^{a}$ School of Biomedical and Biological Sciences, Faculty of Science and Technology, Plymouth University, Plymouth, Devon PL4 8AA, UK \\ ${ }^{\mathrm{b}}$ Agriculture College, Al-Anbar University, Anbar, Iraq
}

\section{A R T I C L E I N F O}

\section{Article history:}

Received 13 November 2012

Accepted 14 November 2012

Available online 24 November 2012

\section{Keywords:}

Wheat genotypes

Frost damage

Cbf expression

Molybdenum application

\begin{abstract}
A B S T R A C T
Wheat is able to cold acclimate in response to low temperatures and thereby increase its frost tolerance and the extent of this acclimation is greater in winter genotypes compared to spring genotypes. Such upregulation of frost tolerance is controlled by $\mathrm{Cbf}$ transcription factors. Molybdenum (Mo) application has been shown to enhance frost tolerance of wheat and this study aimed to investigate the effect of Mo on the development of frost tolerance in winter and spring wheat. Results showed that Mo treatment increased the expression of $C b f 14$ in wheat under non-acclimating condition but did not alter frost tolerance. However, when Mo was applied in conjunction with exposure of plants to low temperature, Mo increased the expression of Cbf14 and enhanced frost tolerance in both spring and winter genotypes but the effect was more pronounced in the winter genotype. It was concluded that the application of Mo could be useful in situations where enhanced frost resistance is required. Further studies are proposed to elucidate the effect of exogenous of applications of Mo on frost resistance in spring and winter wheat at different growth stages.
\end{abstract}

Crown Copyright (c) 2012 Published by Elsevier Masson SAS. All rights reserved.

\section{Introduction}

Low temperature is one of the most important abiotic stresses affecting plant growth, production and distribution throughout the world. Some plants can tolerate low temperatures through a process known as cold acclimation, this is when plants are exposed to low non-freezing temperature $\left(0-4{ }^{\circ} \mathrm{C}\right)[1,2]$. During the acclimation process, many changes occur such as accumulation of osmoprotectants like soluble sugar [3], amines, and compatible solutes such as polyols, proline and betaine [4,5], via activation of low temperature signal transduction pathways which eventually lead to membrane stability and altered gene expression to provide the tolerance at all levels [6]. Recent studies have reported that gene expression for wheat might be changed not just through low temperature $\left(4^{\circ} \mathrm{C}\right)$, but following exposure to some chemicals used for seed priming e.g. Molybdenum (Mo), which can increase CBF expression [7]. Moreover, this study has also shown that these chemicals increased the plants ability to tolerate low temperature through a regulation of abscisic acid (ABA) biosynthesis via Aldehyde oxidase (AO), and the ABA is involved in mediating expression of Cold regulated (COR) genes. Meanwhile, Sun et al. [7] have

\footnotetext{
* Corresponding author. Tel.: +44 (0)7762226146.

E-mail address: mfuller@plymouth.ac.uk (M.P. Fuller).
}

reported that the AO activity, ABA content, and Indole acetic acid (IAA) content increased in -Mo treated wheat leaves. In order to improve our understanding of the molecular basis of cold stress enhanced by Mo application under normal and low temperature, this present work studied frost damage to wheat genotypes in relation to $\mathrm{CBF}$ gene expression under the influence of Mo treatments and low temperature.

\section{Results}

\subsection{Effects of Mo on Cbf14 expression and frost damage to wheat}

The Cbf14 expression under + Mo treatment in both genotypes was significantly higher $(p$ value $<0.001)$ than - Mo after 30 days from sowing and before exposing plants to low temperature (Fig. 1-A). This increase suggests that Mo can induce the transduction pathway for CBF expression in wheat even without exposing plants to acclimating temperatures. However, there were no significant differences in the physiological response of either genotype in response to Mo in terms of frost resistance (Fig. 1-B).

Transcripts levels of Cbf14 were increased markedly after $8 \mathrm{~h}$ exposure to acclimation temperature $\left(4^{\circ} \mathrm{C}\right)$ in both genotypes (Fig. 2) and there was significantly higher transcript abundance in + Mo treated and acclimated plants in both genotypes (Fig. 2). 

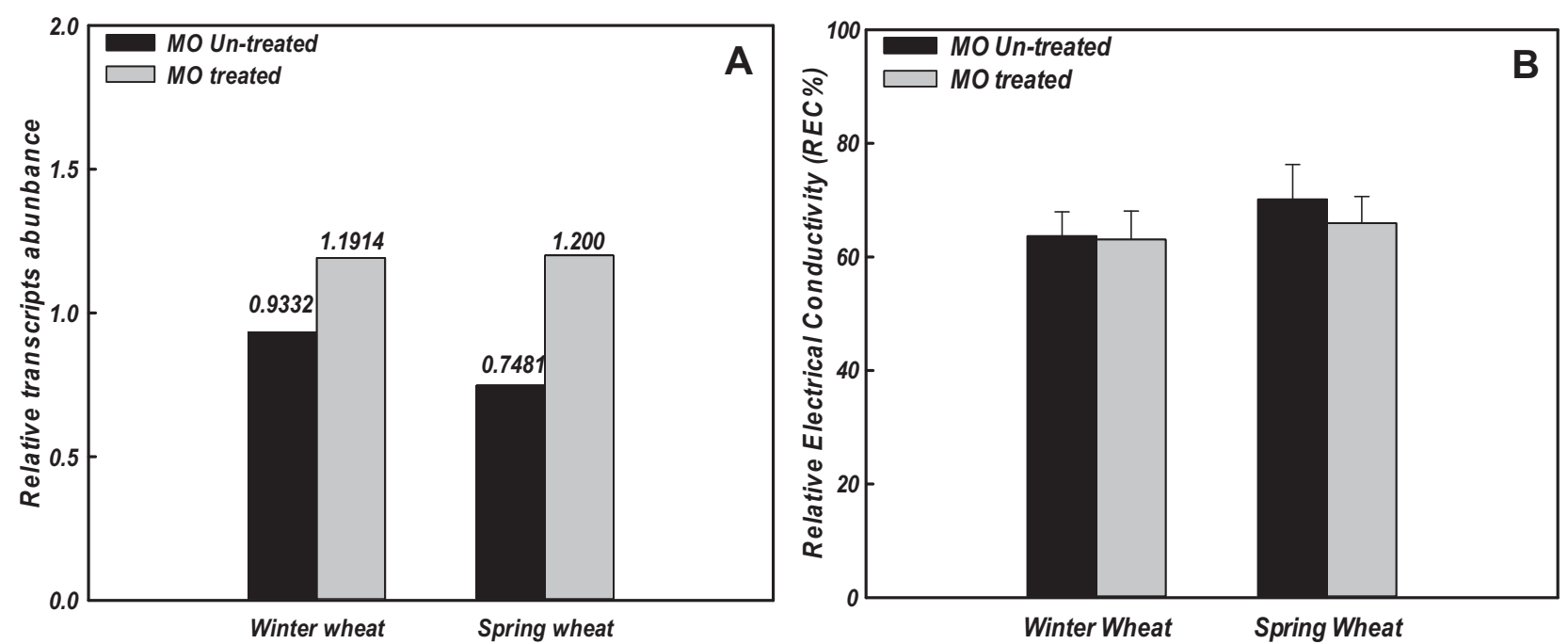

Fig. 1. Effects of molybdenum on Cbf14 expression (A) and frost damage (B), after 30 days from sowing wheat genotypes and before transfer plants to low temperature $\left(4{ }^{\circ} \mathrm{C}\right)$.

The added response to + Mo was proportionately higher in the spring genotype than the winter genotype. After $24 \mathrm{~h}$ the transcript level declined to less than the acclimated only treatment in the spring genotype (Fig. 2 B) and also declined in the winter genotype but was maintained at a significantly up-regulated level compared to the acclimated only treatment (Fig. 2A). The expression of Cbf14 in Mo-treated plants under warm conditions $\left(20^{\circ} \mathrm{C}\right)$ in comparison to acclimating temperatures was very low in both genotypes but there was some significant up-regulation with +Mo in the spring genotype at $24 \mathrm{~h}$. It was clear that for wheat of both genotypes grown under warm conditions $\left(\sim 20^{\circ} \mathrm{C}\right)$ that without + Mo Cbf14 was not expressed.
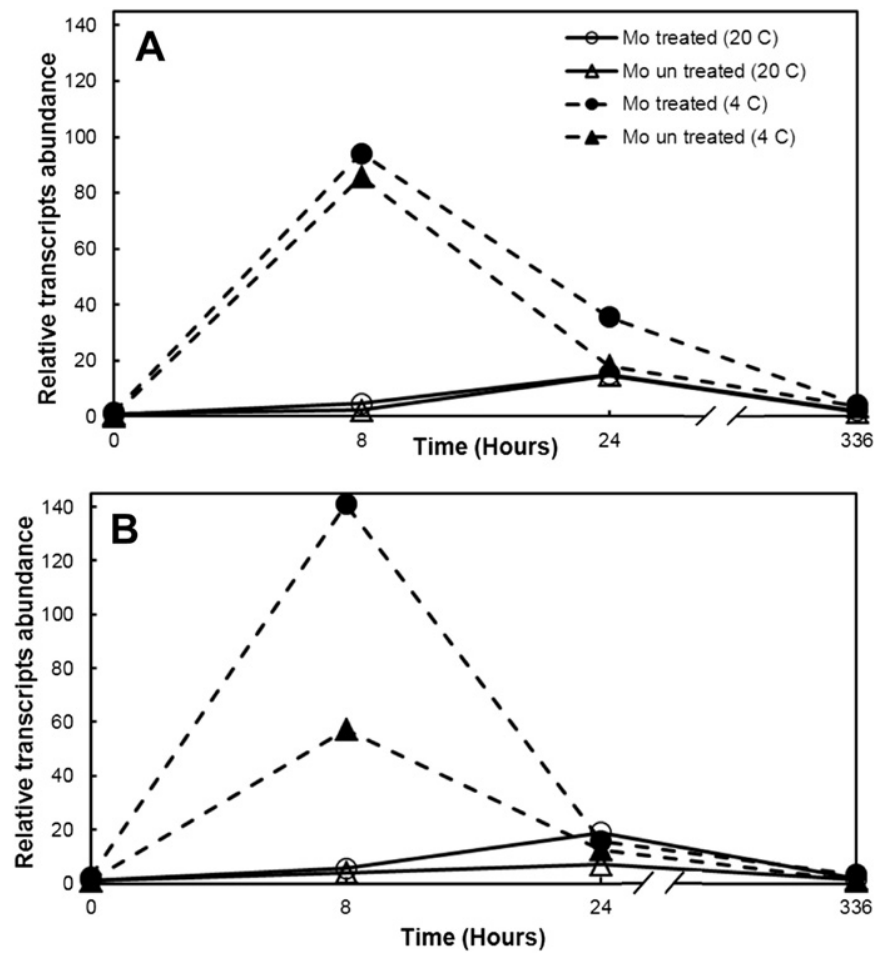

Fig. 2. The effect of molybdenum (solid and open circles) on Cbf14 transcript abundance under normal (solid lines) and acclimating (dotted lines) temperature conditions in (A) winter wheat and (B) spring wheat.
Frost tolerance increased as a result of acclimation of more than 24 h (Fig. 3) and molybdenum (+Mo) enhanced this effect. Frost damage under acclimation was similar in both genotypes, but when plants were exposed to low temperature stress, winter wheat demonstrated significantly improved tolerance $(p<0.05)$ to frost damage (REC 22.58\%) compared with spring wheat (REC 40.68\%) (Fig. 3).

\subsection{Effects of Mo on frost hardiness (LT50) in wheat genotypes}

The application of molybdenum resulted in an increase in frost tolerance in both wheat genotypes (Fig. 4) and the two genotypes
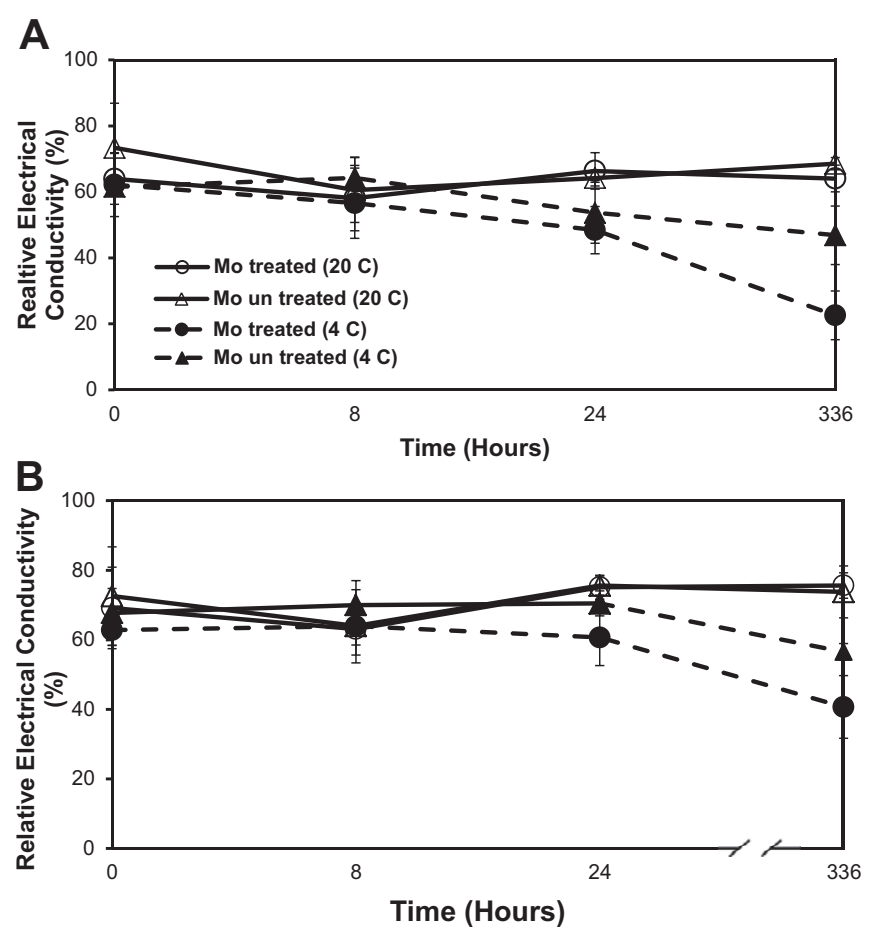

Fig. 3. The effect of molybdenum (solid and open circles) on frost damage under normal (solid lines) and acclimating (dotted lines) temperature conditions in (A) winter wheat and (B) spring wheat. 
A

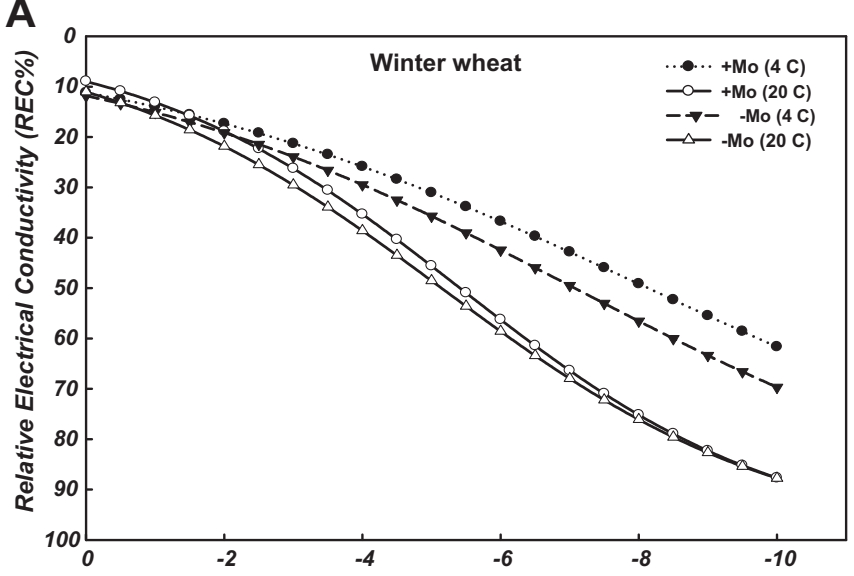

B Temperature (C)

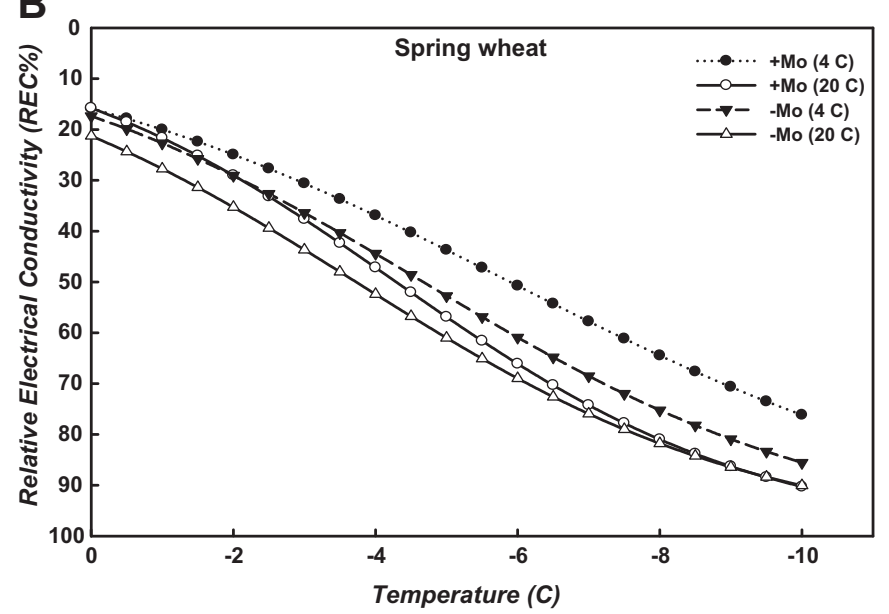

Fig. 4. Logistic differential curves of REC\% for winter (A) and spring (B) wheat following exposure to freezing temperatures.

showed similar patterns in their response to the treatments. Acclimation clearly enhanced frost tolerance in wheat after 14 days exposure to low temperature and the REC\% was significantly $(p<0.000)$ less in acclimated plants with and without Mo application. Mo-treated plants were more tolerant to freezing temperatures compared to acclimation alone. In general, winter wheat had consistently more frost tolerance compared with spring wheat.

LT50 values in acclimated plant were lower than those growing under non-acclimating conditions for both varieties. There were no significant differences between Mo-treated and untreated plants under non-acclimating conditions (Table 1). Winter wheat showed a higher capacity $\left(-8.14{ }^{\circ} \mathrm{C}\right)$ to be acclimated than spring wheat.

Acclimation lowered the LT50 by approximately $2.0^{\circ} \mathrm{C}$ in both winter and spring wheat while the Mo application enhanced the LT50 further by $1.07{ }^{\circ} \mathrm{C}$ and $0.43{ }^{\circ} \mathrm{C}$ in winter and spring wheats respectively.

Table 1

LT50s for the molybdenum ( + Mo) treated and untreated $(-\mathrm{Mo})$ plants in acclimated (CA) and non-acclimated (NA) state.

\begin{tabular}{|c|c|c|c|c|c|c|}
\hline \multirow[t]{2}{*}{ Genotypes } & \multirow[t]{2}{*}{ Mo } & \multirow[t]{2}{*}{ NA } & \multirow[t]{2}{*}{ CA } & \multirow[t]{2}{*}{$\begin{array}{l}\Delta \text { LT50 due to } \\
\text { acclimation }\end{array}$} & \multicolumn{2}{|c|}{$\begin{array}{l}\Delta \text { LT50 due to } \\
\text { Mo addition }\end{array}$} \\
\hline & & & & & NA & CA \\
\hline Winter & $\begin{array}{l}+ \text { Mo } \\
- \text { Mo }\end{array}$ & $\begin{array}{l}-5.43 \\
-5.16\end{array}$ & $\begin{array}{l}-8.14 \\
-7.07\end{array}$ & $\begin{array}{l}-2.71 \\
-1.91\end{array}$ & -0.27 & -1.07 \\
\hline Spring & $\begin{array}{l}+\mathrm{Mo} \\
+\mathrm{Mo}\end{array}$ & $\begin{array}{l}-5.53 \\
-5.02\end{array}$ & $\begin{array}{l}-7.40 \\
-6.97\end{array}$ & $\begin{array}{l}-1.87 \\
-1.95\end{array}$ & -0.51 & -0.43 \\
\hline
\end{tabular}

\section{Discussion}

Molybdenum is an essential micronutrient for plants [8] and since it is a transition element, it can be presented in several oxidation states. It has previously been proposed that molybdenum can be involved in amelioration of frost damage $[9,10]$ and improvement of freezing tolerance in wheat [11,12] but the mechanism for this improvement has not been definitively determined. Mo is not free in cells, since it is very unstable and therefore it would be expected to be in a tight complex with proteins. It is stored in this status and utilises Mo carriers [13,14] when cells require it. There are several possible ways by which Mo could enhance the development of freezing tolerance in plant cells; Mo may increase the anti-oxidative defence by increasing the activity of the anti-oxidative enzymes SOD, CAT and POX [19]. Frost stress imposes induced oxidative stresses by producing Reactive Oxygen Species (ROS), which cause cellular damage [15] and Sun et al. [11] claimed that Mo application enhanced the adaptation of plants to low temperature stress by increasing the ability of scavenging the ROS thus alleviating membrane damage in winter wheat under low temperature. Alternatively, Mo may increase the activity of $\mathrm{AO}$ and thereby the ABA content and it has been found that these were higher in Mo-treated plants compared with Mo untreated plants. ABA biosynthesis through AO can trigger bZIP and the up-regulation of the ABA dependent COR gene expression pathways [7] and thereby protect against frost damage. A third mechanism could be through nitrogen reductase (NR) and enhancing nitrate assimilation [16] as it has been found that NR activity significantly increased in Mo-treated wheat [1719] and in addition $\mathrm{K}^{+}$ions increased and this was associated with protein accumulation [16]. The results presented in the current study provide evidence for a fourth pathway demonstrating that Mo can influence the up-regulation of the CBF pathway and this in turn can lead to COR up-regulation and improvements in frost tolerance. Mo reduced the LT50 by $-1.07{ }^{\circ} \mathrm{C}$ in acclimated winter wheat (Table 1) and we found that Mo application had an effect at the gene expression and increased the transcripts level of $C b f 14$, which in turn activates COR genes and increases protein content in cells and decreases the damage caused by freezing temperatures $[6,20,21]$. Unexpectedly the work found that Cbf14 transcript level was higher in spring wheat especially after $8 \mathrm{~h}$ exposure to acclimation whereas the physiological resistance to frost was less. It is speculated that exogenous Mo application leads to overexpression in Cbf14, which then led to feedback inhibition. This was confirmed after $24 \mathrm{~h}$ exposure to acclimation where Cbf14 transcripts dramatically declined in spring wheat compared to winter wheat, which responded to Mo application in a more consistent manner. The results showed that Mo increased the transcripts levels of $\mathrm{Cbf14}$ at $20{ }^{\circ} \mathrm{C}$ (non-acclimating), in both wheat genotypes and it is suggested that Mo treatment applied as seed priming can increase the constitutive expression of abiotic stress genes (e.g.Cbf14) and when combined with acclimating temperatures, can significantly improve frost stress more than low temperature alone.

It is well documented that wheat can be acclimated and reacclimated to low temperature while it is still in the vegetative phase of growth [22] and LT50 results presented here confirmed that winter wheat was more tolerant to freezing when acclimated than spring wheat (Table 1). It is known that selection for a loss of vernalisation (spring habit) also co-selects for a loss of cold tolerance in wheat as these genes are closely linked [23-26]. Furthermore, wheat genotypes can also differ in the degree of acclimation depending on their growth stage [23,27]. Typically wheat loses its ability to acclimate as it begins to head [28] and this can expose it to severe damage from late season frosts in continental climates [28]. 
The findings here with Mo may offer an opportunity to use Mo to upregulate the CBF pathway and stimulate acclimation in crops threatened with late season frosty weather.

Results showed a strong association between Cbf14 expression and frost damage in winter wheat, while it was much less in the case of spring wheat. This suggests that Cbf14 might not be followed by activation of COR genes in spring wheat and the improvement in Cbf14 expression was because of another pathway. Further studies are needed in order to clarify this molecular response in spring wheat. Prior to acclimation, Mo was able to increase Cbf14 expression, but this increase was small (Fig. 1). However, in the presence of acclimating temperatures, Mo significantly increased transcripts levels of $C b f 14$ and enhanced frost tolerance.

Whilst the results presented here do not fully explain the effects of Mo in frost tolerance they do confirm that Mo can help to upregulate the important transcription factors of cold acclimation and thereby enhance frost tolerance in wheat.

The results here indicate that Mo application increased Cbf14 expression in wheat plants. However, in the absence of acclimating temperatures this increase did not lead to an increase in frost tolerance. When acclimating temperatures were imposed, Mo treatment enhanced the development of frost tolerance in both genotypes but not by the same level. Spring wheat responded more quickly to the application of Mo at the level of Cbf14 expression however, it also dropped away more quickly. Further studies to investigate the use of different concentrations of Mo and different methods of application will be useful on both genotypes in order to see whether the Mo enhancing effect can be optimised further. Furthermore, it would be useful to investigate the effect of Mo application to wheat genotypes at later growth stages to investigate whether it can overcome the development limited expression of frost resistance in wheat.

\section{Materials and methods}

\subsection{Seed treatment with Mo and plant materials}

Seed of two varieties were used, European winter wheat cv. Claire with moderately high vernalisation requirements and moderate frost tolerance and Iraqi spring wheat cv. Abu-Ghraib which has been sown as a winter wheat in mild winter climates. Two treatments ( + Mo and $-\mathrm{Mo}$ ) were applied to seeds of both varieties. Half of the seeds from each genotype were soaked in a solution containing $1 \%$ molybdate $\left[\left(\mathrm{NH}_{4}\right) 6 \mathrm{Mo}_{7} \mathrm{O}_{24} .4 \mathrm{H}_{2} \mathrm{O}\right](0.008 \mathrm{M})$ for $8 \mathrm{~h}$ at $20^{\circ} \mathrm{C}[29,30]$, and the other half were soaked in distilled water for the same period (hydro priming) and then air dried until they reached their original moisture content (14\%) [31]. Seeds were then sown in trays in a growth a cabinet (Snijder scientific) in order to obtain seedlings at the same physiological age. Seedlings were transplanted into pots $(127 \mathrm{~mm} \times 127 \mathrm{~mm} \times 152.4 \mathrm{~mm})$ with 9 seedlings per pot, containing John Innes No. 1 compost. Seedlings were left to grow in a semi-controlled greenhouse $\left(\sim 20^{\circ} \mathrm{C}\right)$ for 30 days until the $3-4$ leaf stage (GS13-14) [32]. Pots of each treatment were subdivided into two groups $(n=7)$, and placed either into an acclimation chamber at $4{ }^{\circ} \mathrm{C}, 8 \mathrm{~h}$ photoperiod (PAR $177 \mu \mathrm{mol} \mathrm{m}^{-2} \mathrm{~s}^{-1}$ ) for 14 days, or a growth cabinet at $20^{\circ} \mathrm{C}$ at the same photoperiod and PAR. Samples for both frost tolerance assessment and molecular analysis were taken after $0,8,24 \mathrm{~h}$ and 14 days from transferring plants to the new conditions. Samples for molecular study were stored at $-80^{\circ} \mathrm{C}$ until analysis.

\subsection{Frost tolerance assessment}

Frost damage was estimated as Relative Electrical Conductivity (REC\%). Leaves were cut and put singly in labelled boiling tubes $(75 \mathrm{~mL})$ in order to expose them in stepwise intensities of low temperature stress $0,-4,-6,-8,-10{ }^{\circ} \mathrm{C}$ with a $2 \mathrm{~h}$ hold at each temperature after which samples were removed. A small piece of ice was added to each tube at $0{ }^{\circ} \mathrm{C}$ to facilitate ice nucleation in the plant material being tested. All frozen samples were placed at $4{ }^{\circ} \mathrm{C}$ overnight to facilitate slow defrosting. Sufficient distilled water (approx. $20 \mathrm{~mL}$ ) was then added to the tubes to cover the leaves and a lid was placed on each tube and then incubated at $20^{\circ} \mathrm{C}$ for $24 \mathrm{~h}$ and the Electrical Conductivity (EC1) of the solution measured. Tubes were then autoclaved at $121^{\circ} \mathrm{C}$ for $15 \mathrm{~min}$ and again incubated for $24 \mathrm{~h}$ at $20^{\circ} \mathrm{C}$ and then the EC re-measured (EC2). The REC $\%$ was calculated as: REC\% $=\mathrm{EC} 1 / \mathrm{EC} 2 \times 100$ [33-35].

\subsection{Total mRNA extraction, $C D N A$ synthesis and RT-PCR}

Frozen leaves ( $100 \pm 10 \mathrm{mg}$ ) were ground in liquid nitrogen with a mortar and pestle. The total RNA was isolated using Sigma reagents (Sigma-Aldrich: spectrum plant total RNA kit, Cat \# STRN50) according to the manufacturer's instructions. Extracted RNA was quantified using the Nano drop 1000 technique to estimate its concentration and then stored at $-80^{\circ} \mathrm{C}$. The first strand cDNA was obtained by using M-MLV Reverse Transcriptase (Sigma: M1302) in $20 \mu \mathrm{L}$ volume. Forward and reverse PCR primers were designed for the Cbf14 gene, which has previously been shown to give the highest transcript levels within 15 min [36]. The wheat 18s rRNA was used as an endogenous control. Primers for the genes were designed with gene sequences obtained from Blast software to give the following primer templates: forward primer Cbf14-int-F 5'-CCGTTCAGCACCGCCAAGGA-3', reverse primer Cbf14-Int-R 5'-CCATGCCGCCAAACCAGTGC- $3^{\prime}$, forward 18 s rRNA $5^{\prime}$-TGTGCCTAACCCGGGGGCAT$3^{\prime}$ and reverse 18s rRNA 5'-GAGCGTGTTTTGGCGTGACGC-3'. All primers were obtained from Eurofins MWG. cDNA was used as a template for the RT-PCR detection system. The cDNA for the samples was used as template for the real time PCR reaction (Applied Biosystem, StepOne Pluse) with SYBR Green JumpStart Taq ReadyMix (Sigma kit Cat. \#S4438-100RXN). The PCR thermal cycle was optimised to be as follows: 10 min denaturation at $95{ }^{\circ} \mathrm{C}$ and then 40 cycles of $15 \mathrm{~s}$ at $95^{\circ} \mathrm{C}$ and $1 \mathrm{~min}$ at $60^{\circ} \mathrm{C}$. The melting curve was set up at the end of the 40 cycle for $15 \mathrm{~s}$ at $95^{\circ} \mathrm{C}, 1 \mathrm{~min}$ at $60^{\circ} \mathrm{C}$ and $15 \mathrm{~s}$ at $95^{\circ} \mathrm{C}$ in order to be sure that only the gene of interest and the control gene were amplified.

\section{Acknowledgement}

The authors gratefully acknowledge the Ministry for Higher Education, Iraq for funding of a PhD Scholarship for Mohammed AlIssawi.

\section{References}

[1] D.B. Fowler, Cold hardy wheat, in: Proceedings Saskatchewan Soil Conservation Association 19th Annual Conference (2007), pp. 33-38.

[2] M.F. Thomashow, Plant cold acclimation: freezing tolerance genes and regulatory mechanisms, Annual Review of Plant Physiology and Plant Molecular Biology 50 (1999) 571-599.

[3] M. Uemura, G. Warren, P.L. Steponkus, Freezing sensitivity in the sfr4 mutant of Arabidopsis is due to low sugar content and is manifested by loss of osmotic responsiveness, Plant Physiology 131 (2003) 1800-1807.

[4] B.P. Naidu, Separation of sugars, polyols, proline analogues and betaine in stressed plant extracts by high performance liquid chromatography and quantification by ultra violet detection, Australian Journal of Plant Physiology 25 (1998) 793-800.

[5] F. Allard, M. Houde, M. Korol, N.P. Ivanov, F. Sarhan, Betaine improves freezing tolerance in wheat, Plant and Cell Physiology 39 (1998) 1194-1202.

[6] M.F. Thomashow, Molecular basis of plant cold acclimation: insights gained from studying the CBF cold response pathway, Plant Physiology 154 (2010) 571-577.

[7] X. Sun, C. Hu, Q. Tan, J. Liu, H. Liu, Effects of molybdenum on expression of cold-responsive genes in abscisic acid (ABA)-dependent and ABAindependent pathways in winter wheat under low-temperature stress, Annals of Botany 104 (2009) 345-356.

[8] B. Kaiser, K. Gridley, J. Ngaire Brady, T. Phillips, S. Tyerman, The role of molybdenum in agricultural plant production, Annals of Botany 96 (2005) 745-754 
[9] W. Li, Z. Wang, G. Mi, X. Han, F. Zhang, Molybdenum deficiency in winter wheat seedlings as enhanced by freezing temperature, Journal of Plant Nutrition 24 (2001) 1195-1203.

[10] Y.Q. Du, Y.H. Wang, W.X. Wei, Z.R. Wang, Effect of molybdenum fertilizer application on the nitrogen and molybdenum nutritions of wheat, Journal of Huazhong Agriculture. 13 (4) (1994) 384-389.

[11] X.-C. Sun, C.-X. Hu, Q.-L. Tan, Effects of molybdenum on antioxidative defense system and membrane lipid peroxidation in winter wheat under low temperature stress, Journal of Plant Physiology and Molecular Biology 32 (2) (2006) 175-182.

[12] Y.H. Wang, W.X. Wei, Q.L. Tan, A study on molybdenum deficiency and molybdenum application of winter wheat in yellow-brown soil of Hubei province, Soil Fertility 3 (1995) 24-28.

[13] R. Vunkova-Radeva, J. Schiemann, R.-R. Mendel, G. Salcheva, D. Georgieva, Stress and activity of molybdenum-containing complex (molybdenum cofactor) in winter wheat seeds, Plant Physiology 87 (1988) 533-535.

[14] K.V. Rajagopalan, J.L. Johnson, The pterin molybdenum cofactors, Journal of Biological Chemistry 267 (1992) 10199-10202.

[15] U. Sattler, P. Calsou, S. Boiteux, B. Salles, Detection of oxidative base DNA damage by a new biochemical assay, Archives of Biochemistry and Biophysics 376 (2000) 26-33.

[16] H.M. Hamdia, H.M. El-Komy, M.A.K. Shaddad, A.M. Hetta, Effect of molybdenum of nitrogenase activities of wheat inoculated with Azospirillum brasilense growth under drought stress, General and Applied Plant Physiology 31 (2005) 43-54.

[17] K.L. Hale, S.P. McGrath, E. Lombi, S.M. Stack, N. Terry, I.J. Pickering, G.N. George, E.A.H. Pilon-Smits, Molybdenum sequestration in Brassica species. A role for anthocyanins, Plant Physiology 126 (2001) 1391-1402.

[18] B. Stallmeyer, G. Schwarz, J. Schulze, A. Nerlich, J. Reiss, J. Kirsch, R.R. Mendel, The neurotransmitter receptor-anchoring protein gephyrin reconstitutes molybdenum cofactor biosynthesis in bacteria, plants, and mammalian cells, Proceedings of the National Academy of Sciences 96 (1999) 1333-1338.

[19] M. Yu, C. Hu, Y. Wang, Influences of seed molybdenum and molybdenum application on nitrate reductase activity, shoot dry matter, and grain yields of winter wheat cultivars, Journal of Plant Nutrition 22 (1999) 1433-1441.

[20] K.R. Jaglo-Ottosen, S.J. Gilmour, D.G. Zarka, O. Schabenberger, M.F. Thomashow, Arabidopsis CBF1over-expression induces COR genes and enhances freezing tolerance, Science 280 (1998) 104-106.

[21] E.J. Stockinger, S.J. Gilmour, M.F. Thomashow, Arabidopsis thaliana CBF1 encodes an AP2 domain-containing transcriptional activator that binds to the C-repeat/DRE, a cis-acting DNA regulatory element that stimulates transcription in response to low temperature and water deficit, Proceedings of the National Academy of Sciences 94 (1997) 1035-1040.
[22] S. Mahfoozi, A.E. Limin, D.B. Fowler, Developmental regulation of lowtemperature tolerance in winter wheat, Annals of Botany 87 (2001) 751-757.

[23] M. Ishibashi, F. Kobayashi, J. Nakamura, K. Murai, S. Takumi, Variation of freezing tolerance, Cor/Lea gene expression and vernalization requirement in Japanese common wheat, Plant Breeding 126 (2007) 464-469.

[24] G. Galiba, V. Attila, L. Chengxia, S. Alexandra, J. Dubcovsky, Regulatory genes involved in the determination of frost tolerance in temperate cereals, Plant Science 176 (2009) 12-19.

[25] G. Galiba, S.A. Quarrie, J. Sutka, A. Morgunov, J.W. Snape, RFLP mapping of the vernalisation (Vrn1) and frost resistance (Fr1) genes on chromosome $5 \mathrm{~A}$ of wheat, Theoretical and Applied Genetics 90 (1995) 1174-1179.

[26] F. Kobayashi, S. Takumi, S. Kume, M. Ishibashi, R. Ohno, K. Murai, C. Nakamura, Regulation by $\mathrm{Vrn}-1 / \mathrm{Fr}-1$ chromosomal intervals of CBF-mediated Cor/Lea gene expression and freezing tolerance in common wheat, Journal of Experimental Botany 56 (2005) 887-895.

[27] A. Distelfeld, C. L, J. Dubcovsky, Regulation of flowering in temperate cereals, Current Opinion in Plant Biology 12 (2009) 1-7.

[28] M. Al-Issawi, H.Z. Rihan, N. El-Sarkassy, M.P. Fuller, Frost hardiness expression and characterisation in wheat at ear emergence, Journal of Agronomy and Crop Science (2012) 1-9.

[29] M.Z. Jafar, M. Farooq, M.A. Cheema, I. Afzal, S.M.A. Basra, M.A. Wahid, T. Aziz, M. Shahid, Improving the performance of wheat by seed priming under saline conditions, Journal of Agronomy and Crop Science 198 (2012) 38-45.

[30] Z.Y. Wang, Y.L. Tang, F.S. Zhang, Effect of molybdenum on growth and nitrate reductase activity of winter wheat seedlings as influenced by temperature and nitrogen treatments, Journal of Plant Nutrition 22 (1999) 387-395.

[31] A. Ahmadi, A. Mardeh, K. Poustini, M. Jahromi, Influence of osmo and hydropriming on seed germination and seedling growth in wheat (Triticum aestivum L.) cultivars under different moisture and temperature conditions, Pakistan Journal of Biology Science 10 (22) (2007) 4043-4049.

[32] J.C. Zadoks, T.T. Chang, C.F. Konzak, A decimal code for growth stages of cereals, Weed Research 14 (1974) 415-421.

[33] A. Aronsson, Frost hardiness in Scots pine (Pinus silvestris L.). II. Hardiness during winter and spring in young trees of different mineral nutrient status, Studia Forestalia Suecica. ISSN: 0039-3150 155 (1980). ISSN: 0039-3150 1-27.

[34] M.P. Fuller, M. Wisniewski, The use of infrared thermal imaging in the study of ice nucleation and freezing of plants, Journal of Thermal Biology 23 (1998) 81-89.

[35] J. Levitt, Response of Plant to Environmental Stresses, second addition ed., Academic Press, New Work, 1980.

[36] A. Vágújfalvi, A. Aprile, A. Miller, J. Dubcovsky, G. Delugu, G. Galiba, L. Cattivelli, The expression of several Cbf genes at the Fr-A2 locus is linked to frost resistance in wheat, Molecular Genetics and Genomics 274 (2005) 506-514. 